\title{
PUBLIC OPINION DURING THE WATERGATE CRISIS
}

\author{
JOHN P. ROBINSON \\ University of Michigan
}

Mass media are considered by many observers as the major distinguishing feature of modern society. Individuals who live in media-rich environments can expect to be increasingly dependent on media; and the more successful media, in turn, can expect to become increasingly efficient at providing content geared to their audiences. In terms of such a process, the mass audience would tend rather slowly to have their basic political beliefs and attitudes shaped as a result of exposure to single stories or messages in the mass media, but would probably shift in line with long-range themes or "meta-messages" resulting from repeated media political coverage. Thus, only now can we begin to grasp what may be the important long-term impacts of television on political life in America-the shifting of interest away from local affairs to national affairs-the conveying of a skeptical-if not cynical-portrayal of the political process, and the acceleration of the rise and fall of political candidates.

COMMUNICATION RESEARCH, VOI. 1 No. 4, October 1974

(C) 1974 Sage Publications, inc. 
These three hypothetical long-term processes are highly relevant in our understanding the political turmoil that was generated by the Watergate scandals. However, it is difficult to find empirical support or even to suggest methods whereby these hypotheses could be empirically validated. For example, take the proposition of increased interest in national affairs. One might have noted the prevalence of national versus local content that people mention in things that they say are interesting or important to them. Or one could have asked people directly to rate the degree to which national and local matters are important to them on some sort of common scale. Unfortunately, no known researcher had the foresight to ask such questions of a representative sample prior to and during the arrival of television coverage of politics. The accelerated pace of political careers has become a commonly accepted feature of the American scene. Yet this phenomenon also has not been empirically assessed.

The hypothesis of rising cynicism is supported by recent survey evidence documenting the drastic drop in public trust in government (Miller, Brown, and Raine, 1973), during an era of increased media political coverage. But the evidence is less convincing about the media's direct responsibility for this trend (Robinson, 1972).

At least three levels of analytical knowledge about trends in public opinion can be distinguished. The most basic level is having comparably (preferably exactly) worded questions asked at two points in time of equivalent representative samples. This level of analysis, sufficient to establish the existence of a trend, is now a common feature of reports from Gallup and Harris polls, providing invaluable historical archives from which to document the ebbs and flows of public opinion. More elaborate conclusions can be drawn if various segments within two samples are examined separately to determine whether a trend has been more pronounced in certain segments of society.

One might then speculate about whether something peculiar to one segment of society made it more prone to change than other segments. This level of analysis is increasingly used in 
Gallup and Harris reports and will receive greater attention as the current "social indicators" movement gathers momentum. In the context of political media research, recent examples of this strategy can be found in Wright's (1972) contention that middle-class high media users were most changed by media coverage of the Vietnam war, and in Robinson's (1972) examination of the degree to which deteriorating trust in government was more common among those exposed to network television's predominantly negative political coverage.

Conclusions based on such research are limited by the fact that different people have been interviewed in the different samples, thus leaving unresolved the degree to which more idiosyncratic individual factors are at work. This is most crucial in determining changes on that variable which itself is under investigation. In the case of trust in government, for example, one cannot know whether individuals who were already cynical about politics have become more cynical while the rest have retained their basic optimism.

Such conclusions and the greater confidence possible in establishing links between audience change and media exposure depend on using information from the same samples interviewed at different times. This panel design was a major feature of the Michigan Survey Research Center's study of the social context of mass media effects, a project supported by the John and Mary Markle Foundation. The project is being conducted in Flint, Michigan, and Toledo, Ohio, both about fifty miles from Detroit. Obviously it cannot be claimed that reaction to Watergate in these two cities is representative of national trends. However, it is a sample about which we have considerable knowledge of the media environment, and one on which repeated measures are available. The complexity of the analysis and the fact that the project is still in process at the time of this writing, preclude results at the most powerful third level of analysis noted above. Nevertheless, we might assume that much of what will be revealed by the first level of analysis in this paper will anticipate what will emerge from more advanced analyses. 


\section{STUDY DESIGN}

The basic strategy in our first phase of this study involved collecting general data on political and social attitudes from a cross-section of about 660 respondents in the two cities, then waiting for an event to occur that would affect such attitudes. This would be followed by a reinterview of these respondents to ascertain whether observed attitude change was related to mass media exposure. This strategy verifies people's actual reactions, rather than depending on their later memories of attitudes prior to the event. These follow-up data can be collected quickly by telephone, in contrast to the original measures which are collected in personal interviews in the respondent's home.

In such a new research area, there were, of course, many uncertainties about which type of attitude measures to collect. There was, first of all, the matter of whether to concentrate on individuals, institutions, or issues as attitude objects. There was further the business of anticipating what individuals, institutions, or issues would be attracting newsworthy attention. There was the question of whether to look at specific short-range opinions or longer-range values or stereotypes. There was the possibility of examining matters that received differential treatment in the newspapers versus television. Our decision was to cover as many of these variables as possible, going for breadth at the possible expense of depth. Our initial survey instrument included four types of questions in the in-home interview administered in December 1972 and January 1973:

(1) Ratings of political figures and institutions: For the most part these consisted of ratings on a "feeling thermometer" which ran between 0 degrees (as cold as possible) to 100 degrees (as warm as possible). Ratings were obtained on key political institutions (the Democratic Party, the Republican Party) and on institutions peripherally related to Watergate (big business, rich people). Most centrally, ratings were obtained on Richard Nixon, as well as two other politicians not involved in Watergate, George McGovern and Spiro Agnew. 
(2) Accuracy of media coverage: Questions were asked about the perceived faimess and accuracy of both newspaper and television reporting, which allow an opportunity to examine how an important facet of media credibility was affected by Watergate.

(3) Attitudes about societal trends: Several items in agree-disagree format were used to tap peoples' attitudes toward such matters as the rate of change or state of morals in society. Particularly relevant in connection with Watergate was an item dealing with government snooping in private matters.

(4) Topics of conversation on a particular day: Respondents were also asked to describe conversations about things in both newspapers and television that they had engaged in on the previous day. The questions were included to tap the degree to which various items in the media made their way into everyday conversations.

By the end of January 1973, our initial interviews were completed, and we were geared up to assess the impact of any of several types of events. Our basic survey design put us particularly on the outlook for significant localized events (e.g., a civil disorder, a local scandal, a local philanthropy) that affected one community but not the other. Over the next three months, however, no such event had occurred, and we began to consider larger national events. By early April, it was evident that something was brewing in Washington in connection with the Watergate break-in of June 1972. As more details began to unfold daily in the news media, Watergate took on the dimensions of the "event" we had been hoping to cover, and we developed a research plan to be implemented between May and September of 1973. The design basically called for the breaking up of our original sample randomly into thirds for both Flint and Toledo. One third of the original sample was to be interviewed by telephone in early May, as soon as possible after President Nixon's first address concerning Watergate. A second one-third of the sample would be interviewed a month after the Senate Watergate hearings had been initiated, and the final third after the Senate Watergate hearings had ended. President Nixon's August 15 Watergate speech followed so closely on the 
heels of the closing of these hearings that interviewing was not begun until after his speech.

This paper will concern itself with the total responses of these three subsamples collected during these three time periods. The structure of the study design is similar to that employeed by Lazarsfeld, Berelson, and Gaudet (1948) in their pioneering studies of voting behavior.

Some new questions obviously had to be added in these telephone reinterviews. Three items incorporated into this wave come from the standard government cynicism scale used by Michigan Center for Political Studies. This scale is comprised of a set of questions concerned with how well the government in Washington is being run. ${ }^{1}$ The scale is intended to be nonpartisan, with respondents being instructed before the scale items are asked that "these ideas don't refer to Democrats or Republicans in particular, but just to the government in general."

Most of the other new questions in the telephone interviews centered on Watergate itself. Five sets of Watergate-related questions were asked in each of the three telephone interviews. They measured:

(1) level of attention to Watergate;

(2) good and bad reactions to Nixon's handling of Watergate (openend):

(3) extent of interpersonal conversation about Watergate;

(4) awareness of the nature of the original Watergate event; and

(5) attitudes about aspects of Watergate itse If (closed-ended questions).

The second and third telephone interviews also included some specific questions about the Ervin Committee hearings.

\section{RESULTS}

The major changes in our measures are outlined in Tables 1 and 2. Table 1 contains items included in our initial in-home 
TABLE 1

RESPONSES TO SURVEY ITEMS AT DIFFERENT TIME POINTS

\begin{tabular}{|c|c|c|c|c|c|}
\hline \multirow[b]{2}{*}{. } & \multirow{2}{*}{ 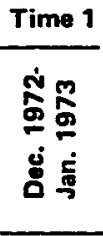 } & \multicolumn{3}{|c|}{ Time 2} & \multirow[b]{2}{*}{$\begin{array}{c}\text { Mean Change } \\
T_{1}-T_{2} \\
\end{array}$} \\
\hline & & $\frac{\stackrel{m}{\sigma}}{\frac{2}{2}}$ & 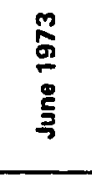 & 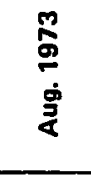 & \\
\hline \multicolumn{6}{|c|}{ Mean rating on scale from 0 to 100 : } \\
\hline Richard Nixon & 59 & 49 & 43 & 44 & -14 \\
\hline Spiro Agnew & 53 & 51 & 45 & 48 & -5 \\
\hline George McGovern & 57 & 49 & 49 & 48 & -8 \\
\hline Republican Party & 55 & 49 & 46 & 46 & -8 \\
\hline Democratic Party & 67 & 63 & 64 & 65 & -3 \\
\hline Big business & 56 & 58 & 53 & 51 & -2 \\
\hline Very rich people & 60 & 53 & 51 & 54 & -7 \\
\hline \multicolumn{6}{|c|}{ Percentage agreeing with statements: } \\
\hline Too much snooping & 45 & 57 & 61 & 57 & +13 \\
\hline Business runs country & 75 & 78 & 83 & 82 & +6 \\
\hline Early leaders were better & 59 & 61 & 67 & 62 & +4 \\
\hline Morais are worse & 73 & 72 & 67 & 72 & -3 \\
\hline Politics too complicated & 80 & NA & NA & 78 & -2 \\
\hline \multicolumn{6}{|c|}{ Percentage saying "reporting usually fair and accurate": } \\
\hline Television news & 57 & 57 & 57 & 63 & +2 \\
\hline Newspaper & 39 & 39 & 40 & 42 & +1 \\
\hline \multicolumn{6}{|c|}{$\begin{array}{l}\text { Percentage mentioning conversation "Yesterday" about } \\
\text { media political content: }\end{array}$} \\
\hline Television & 11 & 23 & 15 & 27 & +11 \\
\hline Newspapers & 4 & 26 & 16 & 14 & +15 \\
\hline $\ln =1$ & $(660)$ & (156) & (154) & (157) & \\
\hline
\end{tabular}

interviews and repeated for the telephone sample; Table 2 contains items asked only in the telephone sample.

To ease presentation of results in terms of trends, figures in the tables refer only to proportions of our samples who expressed opinions on each item-that is, persons giving "don't know" or unascertained responses are excluded from the calculation. $^{2}$

In Table 1, except for the final two items dealing with interpersonal discussion, the questions are mainly attitudinal in 
TABLE 2

RESPONSES TO WATERGATE SURVEY ITEMS AT DIFFERENT TIME POINTS

\begin{tabular}{lccc}
\hline & $\begin{array}{c}\text { May } \\
1973\end{array}$ & $\begin{array}{c}\text { June } \\
1973\end{array}$ & $\begin{array}{c}\text { August } \\
1973\end{array}$ \\
\hline $\begin{array}{l}\text { Percentage paying "great deal" of attention to } \\
\text { Watergate }\end{array}$ & $54 \%$ & $36 \%$ & $36 \%$ \\
$\begin{array}{l}\text { Percentage who talked to more than 5 people } \\
\text { about Watergate }\end{array}$ & 47 & 52 & 63 \\
$\begin{array}{l}\text { Percentage at least partially correct on Water- } \\
\text { gate event information }\end{array}$ & 69 & 76 & 74 \\
$\begin{array}{l}\text { Nixon's handling of Watergate: number of } \\
\text { "good things" minus number of "bad things" }\end{array}$ & -.4 & -.7 & -.8 \\
$\begin{array}{l}\text { Percentage agree with statement: } \\
\text { Watergate things are common in politics }\end{array}$ & 72 & 70 & 73 \\
Watergate is given too much attention in news & 45 & 52 & 51 \\
Nixon knew in advance & 66 & 71 & 58 \\
Trust government less now & 49 & 47 & 54 \\
$\begin{array}{l}\text { Percentage giving listed response: } \\
\text { Trust government only some of the time }\end{array}$ & 50 & 55 & 54 \\
Government is run for a few big interests & 63 & 67 & 67 \\
Quite a few crooked people in government & 53 & 47 & 54 \\
(n =) & $(156)$ & $(154)$ & $(157)$ \\
\hline
\end{tabular}

nature. The greatest and most interesting movement is on the first set of items-the ratings of political figures and institutions. Not surprisingly, the drop in ratings was greatest for Richard Nixon. However, the drop in ratings was almost as severe for George McGovern, who was not directly involved in the Watergate affair. ${ }^{3}$ In this context, there is more significance in Nixon's 6-point decline between May and August than in his 10-point decline between the post-election period and the April resignation of his top White House staff. Moreover, the decline in Nixon's ratings must also be compared to the more negative responses on the thermometer toward all persons and institutions in the time 2 interviews. (This could be due to methodological differences between ratings obtained in person versus by telephone.) Nevertheless, it is clear that the expected 
greater drop in feelings toward the Republican Party than toward the Democratic Party is found in Table 1.

Both parties seem to have suffered after the initial breaking of the Watergate story, but as the Senate hearings progressed, the Democratic Party regained a little of its original strength, while the Republican Party suffered further slight declines. It is also interesting to note that feelings toward two of the Republican Party's traditional constituencies-big business and the rich-also declined.

Not surprisingly, the major shifts in our societal attitude questions occurred for the item dealing with government snooping. In line with the drop in feelings toward big business noted in the top part of Table 1, there is a corresponding increase in agreement with the statement, "Big business really runs the government in this country." There was also slightly increased agreement that the founding fathers of this country got along better than the current leadership structure, but less agreement that morals in this country were getting worse or that politics was, or was becoming, too complicated to understand. The third set of data in Table 1, concerned with the fairness and accuracy of the news media, shows little change. Perhaps the most significant impact of Watergate is told in the entries at the bottom of Table 1 . The Watergate revelations triggered a tremendous increase in public discussion of politically relevant topics, more so after the presidential addresses of April 30 and August 15. The increase appears to have been more pronounced for newspaper coverage than for television coverage.

Responses to the Time 2 questions specifically addressed to the Watergate affair are presented in Table 2. As the Watergate hearings and revelations continued through the summer months, people report paying less attention to Watergate-but talking about it more.

With the increased amount of conversation there is a minor increase in awareness of the event that had precipitated the whole affair. Considering the extensive media coverage, this does not seem to be much of an increase, especially since it is 
due mainly to people who had only a hazy recollection of the event, rather than to those with a more detailed recollection. Moreover, only three percent of both the May and August samples had not heard anything about Watergate. The overall changes for the more attitudinal measures are not as dramatic. There was an increasingly negative cast to our respondents' open-ended evaluation of Nixon's handling of Watergate, but he continued to retain a solid core of supporters of his Watergate policies after his August 15 speech.

Movement on the other attitude measures was not necessarily in a direction negative to the administration. There was a slight increase in the feeling that Watergate was receiving too much attention in the news, no decrease in the popular feeling that Watergate represented anything more than "politics as usual," and a drop in the belief that President Nixon was in on advance planning for the Watergate break-in.

There is, however, evidence of gradual erosion of trust in government as the hearings progressed. As was the case for the Table 1 measures, perhaps the major increase in cynicism toward government occurred just after the initial Watergate revelations. For corroborating evidence on this point, we can turn to interpolation from national sample data on this same measure asked in the Michigan Center for Political Studies' post-election survey. Among residents of smaller Midwestern cities in this national survey (conducted just prior to our initial survey) $46 \%$ felt government could be trusted only some of the time; $55 \%$ felt the government was run for big interests, and only $33 \%$ felt that quite a few people running the government were crooked. Compared to our data at the bottom of Table 2, for each of these three items, we may estimate that the November to May increases in cynicism are at least as great as our May to August differences. The November-May increase is particularly noteworthy for the item on crooks in national government; this belief is held by $20 \%$ more in our May sample than in the previous November-December sample for similar cities. 


\section{DISCUSSION}

Several hypotheses have been advanced about the impact of Watergate revelations on public opinion, and it would be appropriate to examine our findings in the context of three of these hypotheses.

Hypothesis 1: Watergate had as much negative impact on politics in general as it had on the individuals and parties directly involved.

There is certainly much in our findings that can be taken as support for this view. Over $70 \%$ of our samples, even those interviewed after the major Senate hearings, felt that events like Watergate were common in politics. Moreover, in our first telephone reading, taken after the President's April 30 Watergate speech, George McGovern's esteem in the public had fallen almost as sharply as Richard Nixon's. This can also be seen in the drop in the ratings for political parties-Democrats slipping almost as badly as Republicans-and in the decline in supposedly nonpartisan questions about cynicism about government in general. However, there is evidence that this "tarring with the same brush" generalization tailed off after the initial Watergate revelations. As the Senate hearings progressed, Nixon's decline continued, while that of McGovern did not.

The Republican Party continued to fall in esteem, while the Democratic Party regained lost ground. Big business, whose indirect implication in Watergate became apparent in the Senate hearings, began to be seen more negatively. And overall government cynicism apparently did not increase as much as it had between November and May, particularly with reference to the presence of outrightly crooked people in Washington government.

Hypothesis 2. Public interest in Watergate waned considerably as the Senate Watergate hearings dragged on.

There is some evidence in our data to support this hypothesis. Roughly half of those called in our telephone samples 
expressed the view that Watergate was receiving too much attention in the news and self-expressed "great interest" in Watergate was off a third in June and August from what it had been in May. This may also be reflected in the lack of much increase during the summer in public awareness of how the Watergate affair had actually begun. There is stronger evidence, however, against this hypothesis. The ranks of those who felt that Watergate had received too much news attention did not swell appreciably over the summer.

Even in our reading at the mid-point of the summer hearings (without the impetus of a presidential address), the entries at the bottom of Table 1 reveal a level of political communication in the public enormously greater than it had been in December and January. What seems to be most clearly refutable is the contention that by August lack of public interest had built to a point of hostility to the committee. First of all, both level of interest in Watergate and feelings that the news media were giving it too much attention dipped no lower in August than they had in June. (Alternatively, these levels of interest might also have been stimulated by the August 15 presidential address.) Our inference can rest more firmly on responses in June and August to a question about the Watergate hearings themselves. In both samples, there was overwhelming (four or five to one) agreement that the hearings were good rather than bad for our country. ${ }^{4}$ Moreover, our August sample, interviewed after the hearings had ended and exposed to Nixon's criticisms of the committee's work, was somewhat more positively disposed than the June sample had been.

Hypothesis 3: Public trust in the media rose after the Senate hearings provided justification of media exposure of Watergate.

This assumption seems to have spurred a great self-congratulatory movement within the media, but we find no significant increase (save for an upward bump in the August reading) in feelings that newspaper or television reporting was "usually fair and accurate." Nevertheless, it has been argued that public 
concern about the media credibility has been over the media's sins of omission, rather than in their sins of commission, as would be mainly reflected in the fairness and accuracy of reporting. That is, it is the media's failure to report stories fully or from all perspectives which is usually at issue. We found no significant increase in feelings about newspapers across the three time points in general ratings on our 100-point "feeling" scale, a further corroboration of the point.

\section{SUMMARY AND CONCLUSIONS}

The Senate Watergate hearings' revelations resulted in several changes in public opinion that would be expected by common sense-Richard Nixon, the Republican Party, big business, and the very rich all suffered losses in public esteem. President Nixon's handling of the Watergate affair came under increasing criticism. The amount of political discussion in the public mushroomed far above that registered in more normal periods. Cynicism about the government in Washington apparently sank to new lows.

The major shifts in these measures had occurred by May, after resignations of top White House staff, rather than during the period of the Senate Watergate hearings.

However, during the period of the Watergate hearings, negative public reaction became more discriminating, focusing more on those associated with the Republican administration rather than on politicians or government officials in general.

If anything, however, one must be as impressed as much by the stability in public opinion toward the Nixon Administration as by these changes. Given the barrage of negative information about administration personnel and policies that emerged from the Senate hearings and other media reports (to say nothing of the heavily adverse reaction to administration economic policies during the same period), it is simply amazing that, by the end of his long hot summer, Richard Nixon's esteem in our two cities had declined only a little more than McGovern's had. One can become thoroughly impressed (or, discouraged) by other 
evidence of stability of public opinion. There was no desertion from the ranks of the majority, who felt that Watergate represented nothing out of the ordinary in politics. There was only an insignificant shift in the proportions concerned about the declining state of morals in this country. No solid evidence of any increase in media credibility could be found.

It is worth noting that, in our initial analyses, esteem for Nixon drops most precipitously among two contrasting groups-those who watched the hearings regularly, and those who missed them completely. This suggests that a detailed panel analysis of our data might document two separate processes, only one of which would be explained by Robinson's (1972) proposition that people most exposed to the media would be most negatively influenced by the negative image of the President portrayed in the hearings.

Other research may illuminate whether other "spin-off" messages from Watergate have slowly seeped into public consciousness: insecurity about the power invested in the presidency; flaws in campaign financing procedures; too-cozy relations between government and big business; and questioning of slogans used to defend governmental policy, such as "national security" and "law and order." The impact of such subtle messages is difficult to measure quantitatively by traditional social science approaches, and yet these messages most surely will affect the way politicians structure future explanations of their policies to the public.

\section{NOTES}

1. These items were originally included in pretests of our initial interview but had to be dropped in the process of shortening the final interview instrument; the belief expressed by some of our colleagues that the scale had probably "bottomed out" by November 1972 also influenced this unfortunate decision.

2. Exact tests of statistical significance have not been calculated here. As a rough gauge, differences between two of our telephone samples which are roughly in the $50 \%$ range would have to exceed $5 \%$ to be statistically significant at the .05 level. 
3. Note, however, how relatively isolated Spiro Agnew was from this seeming backlash. This is especially true for the final August 1973 reading, which was taken only a few days after his vigorous denial of the accusations that would shortly bring about his conviction and resignation. At this time, Agnew's ratings had increased over his June ratings.

4. There was even more solid support for the fairness of the hearings. Of those who had heard anything about the Senate hearings and expressed an opinion, 87\% felt that the Senate Committee had been "fair to the Nixon Administration," compared to only $6 \%$ who felt that the committee had been "unfair to the Nixon Administration."

\section{REFERENCES}

LAZARSFELD, P. F., B. R. BERELSON, and H. GAUDET (1948) The People's Choice. New York: Columbia Univ. Press.

MILLER, A. H., T. A. BROWN, and A. S. RAINE (1973) "Social conflict and political estrangement, 1958-1972." Presented to the meetings of the Midwest Political Science Association, Chicago.

ROBINSON, J. P. (1972) "Perceived media bias and the 1968 vote: can the mass media affect behavior after all?" Journalism Q. 49 (Summer): 239-246.

ROBINSON, M. (1972) "Public affairs television and the growth of political malaise." Ph. D. dissertation. University of Michigan.

WRIGHT, J. (1972) "Life, Time and the Fortunes of war." Trans-Action (January): 42-52.

John P. Robinson is a study director in the Survey Research Center, and an Assistant Professor of Journalism, at the University of Michigan, where he received his Ph.D. He has served as research coordinator for the U.S. Surgeon General's Scientific Advisory Committee on Television and Social Behavior. He gratefully acknowledges the skilled assistance of Paula Linden in preparing this report. 